\title{
ANALYSING SERVICE QUALITY AND ITS RELATION TO CUSTOMER SATISFACTION AND LOYALTY IN SPORTSWEAR RETAIL MARKET
}

\author{
Canan SARICAM* \\ Istanbul Technical University, Faculty of Textile Technologies and Design, Inonu Cad. No: 65 34437, Gumussuyu Beyoglu Istanbul, Turkey \\ *Corresponding author. E-mail: saricamc@itu.edu.tr
}

\begin{abstract}
:
The sportswear industry has a growing market globally. In the sportswear retail market, where the primary focus is on providing customers the product, but provision of the necessary ancillary service also takes place, the service quality and its relation to customer satisfaction and customer loyalty are important. With an attempt to find out this relationship, the data for this study was obtained from 251 people living in Turkey. The service quality was described as a second-order construct with the dimensions proposed in SERVQUAL scale. Confirmatory factor analysis and structural equation modeling were used to analyze and validate the model. The findings showed that the service quality, together with the relevant dimensions, tangibles, reliability, and assurance, has an influence on the customer satisfaction but not on the customer loyalty. Nonetheless, it was confirmed the customer satisfaction has an impact on the customer loyalty.
\end{abstract}

\section{Keywords:}

Service quality, customer, satisfaction, loyalty, sportswear, retail market

\section{Introduction}

The sportswear industry is a large and growing market globally, driven by the increasing amount of products demanded by the customers and introduction of diversified supply to satisfy these high and varied demands. According to the Global Sportswear Industry Research Report by QY Research, the sportswear retail market was 84.1 billion USD in 2018, and is estimated to grow more rapidly in the near future; to be precise, it is estimated to reach 108.7 billion USD by the end of 2025 [1]. This is because the sportswear products are now purchased for daily use as a casual fashion outfit due to the tendency of the customers to prefer more casual and informal wear [2-3]. In addition to this, the COVID-19 pandemic has resulted in a specific increase on the demand for this product category [4]. The demand-driven activities of the health and wellness conscious customers, who adopt sports activities as a lifestyle, have also increased the amount and variety of the demand for the functional as well as fashionable sportswear products. Since the sportswear products are a special type of product category for which the innovativeness and product quality are rated at higher ranks when compared with the other type of fashion products, the manufacturers have begun to use innovative materials and integrate technological improvements into their production processes to compete with their rivals. The effort put on the innovativeness of the sportswear products such as suits for swimming and diving or surfing and apparel for skiing caused a constant value growth for the sportswear products [2].
Nonetheless, presenting innovative products is not the only area of competition for the sportswear retailers. The competition is becoming more intense also in terms of marketing activities. In the sportswear retail stores, where special types of products meet with the customer, the service offered with the product is as important as the product features. In fact, in Levitt's concept of the total product, the product is stated to be consisted of four layers, which are the core product corresponding to the generic product, the expected product covering the features and services expected by the customers, the augmented product covering the features and services not expected by the customers, and finally the potential product covering the new methods and new ideas that are available[5]. Augmented products, which are the combination of products and services, provide multiple benefits that satisfy the needs of the customers [6-7]. On the other hand, depending on better education and increased communication, today's savvier, better informed, more sophisticated, and discriminating customers request high quality service as well as high quality products [7]. Therefore, the sportswear retailers should dedicate themselves to providing a good service as a part of an augmented product to ensure a pleasurable experience and build long-lasting relationships with their customers.

In fact, the delivery of high service quality is essential for any type of retailer, since the number of satisfied customers, who would continue purchasing and increase their profitability, might become larger [8]. The satisfied customers would more probably talk about their good experiences; on the other hand, dissatisfied customers would use negative word-of-mouth and 
switch to other brands or stores [8-9]. High service quality might also increase customer loyalty, which results in a decrease in the elasticity to the price and guarantee any number of possible future visits to the store [10]. Although earlier in time customer loyalty was associated with only a specific brand, retailer, or store and thus oriented toward a tangible object, its concept has presently been extended to cover intangible features such as service, brand, retailer, or store image [11]. Confirmed to have a strong influence on creating positive image [12], the service quality and its effects on customer satisfaction and loyalty in retailing have long been examined and the relationships among these issues have been discussed.

Having been proposed as a valuable tool for improving the competitive positioning in the market, by increasing the satisfaction and influencing the loyalty, service quality has also drawn the attention of those researchers who are occupied with the field of apparel retailing [13]. The studies regarding service quality in apparel retailing used different approaches for measuring the service quality where most researchers preferred to use multi-dimensional scales such as service quality scale (SERVQUAL) and retail service quality scale (RSQS) [13-15]. Although there is no comprehensive study that measures the quality of service using a widely accepted scale, the service quality was confirmed to have impact on both customer satisfaction and loyalty. On the other hand, the studies hypothesized that the dimensions of the service quality, which were appealing to the consumers, have changed according to the industry, retail type, and product category [16]

Nonetheless, only a very limited number of studies specifically dealt with sportswear retail market presenting primarily functional as well as practical and fashionable items [2, 17] and therefore requiring a specified service. Within the only two studies observed so far, Chang et al. identified the impact of service quality on customer satisfaction and in turn wordof-mouth and retail patronage behavior. In the study, the service-quality-related construct was restricted with the store employees' behavior and the expertise possessed by them [2]. $\mathrm{Li}$ et al. searched the effect of service quality on the satisfaction and loyalty of ten world-famous sportswear brands' customers. Service quality was questioned with only two general items, which are the perception and expectation of service quality [18]. Thus, the literature lacks a comprehensive study specifically focused on the retailers selling sportswear products.

Considering the growth of the sportswear retail market and the significance of the service quality for the customers, there is a need for a deeper understanding of customers' perception of service quality offered by the sportswear retailers. Therefore, this article aims to address this gap in the literature and to explore the relationships between service quality, customer satisfaction, and loyalty in the sportswear product category and sportswear retail market.

\section{Theoretical background and research hypothesis}

\subsection{Measurement of service quality and SERVQUAL}

Measuring and evaluating the quality of the services provided by the sportswear companies is a difficult task due to the intangible aspects of the service. In addition to the challenges that arise owing to the intangible nature of services, the subjective evaluation of the customers makes the measurement of service quality more difficult. Thus, researchers have identified different dimensions that are configured to measure the quality of the service objectively. A service quality measurement approach was proposed with two aspects, which are technical quality and functional quality. The technical quality was about what the customer was receiving, whereas the functional quality was about the manner the service that was delivered [19]. Lehtinen and Lehtinen introduced two approaches to examine service quality as well [20]. The first approach includes three dimensions related to the service production process. They are physical quality, interactive quality, and corporate quality. The second approach has two dimensions, which are process quality and output quality of service production. All these approaches refer to the customers' perception of the service quality.

Service quality has also been examined by Parasuraman et al., who developed a widely used scale for measuring the service quality, namely SERVQUAL [21]. The scale includes five dimensions, which are tangibles, reliability, responsiveness, assurance, and empathy. Tangibles are related with the physical facilities, equipment, and the appearance of the personnel; reliability is related with the ability of performing the promised service dependably and accurately; responsiveness is related with the willingness to help customers and to provide prompt service; assurance is related with the knowledge and courtesy of employees and their ability to convey the purported uniqueness of the concerned brand in a way that prompts the customer to repose trust and confidence in it, and finally, empathy is related with the caring and individualized attention the company provides to its customers [22]. The model proposed by Parasuraman et al. measures service quality by identifying gaps between customers' expectations, which are the values the customers feel that the service provider should offer, and customers' perceptions corresponding to the performance of the service provider [21-22]. On the other hand, SERVQUAL scale was applied as a perception-only scale, where the scale was used once to evaluate the perceived service quality of the customers [23-24]. In the performance-only model developed by Cronin and Taylor, the use of the perceptions-only scale was adopted to facilitate measuring of the service quality, and the scale used for this purpose was known by the name SERVPERF [25]. Since it was used as a performance-only scale, this scale was found to be reliable for understanding the customers' perceptions of retail service quality. Although many scales were proposed for retail industry, SERVQUAL and SERVPERF scales maintained their reputation as the major scales to be used for measuring service quality. 
Nonetheless, as a basic tool for measuring service quality with its multi-dimensional structure, SERVQUAL scale was used as a second-order construct due to the difficulty in differentiating the five dimensions faced by some researchers [26]. This was attributed to the high correlations between some dimensions, which cause a lack of discriminant validity and overlap of conceptual definitions of some dimensions that were supported by the studies evaluating content validity [27-28]. Thus, the dimensions of the scale were captured through a second-order variable, and hierarchical structures were described. In these studies, hierarchical structures were adopted either to produce a second-order construct by combining five dimensions as a whole or to produce two or three second-order constructs by combining the dimensions in pairs or triples. The effective use of SERVQUAL as a second-order construct was supported in several studies so far [29-30].

\subsection{Service quality, customer satisfaction and loyalty}

The customer satisfaction, the customer loyalty, and their relation to the service quality have been highly discussed within the literature. Nevertheless, the studies differed from each other with regard to the definitions and measurements of the service quality, customer satisfaction and loyalty, and the field of application (different retail types and different product categories).

The customer satisfaction was simply defined as the degree up to which customers are satisfied and pleased with the shopping experience [31]. In some studies, it was established to have a similar meaning to service quality, where it was identified as a post consumption experience based on the comparison of perceived quality against expected quality [32]. Some researchers integrated emotion to the definition of customer satisfaction and described the customer satisfaction as a reaction, which was to be based on an assessment of the extent of emotional connection [33]. Further, the customer satisfaction was handled as the sum of cognitive and affective responses to a service incident or sometimes to a long-term service relationship [16, 33, 34]. On the other hand, the customer loyalty was simply defined as a commitment to rebuy or patronize a preferred product or service; a favorable attitude toward a brand, or a situation when repeat purchase behavior is accompanied by a psychological bond [32, 35]. The customer loyalty was stated to have the behavioral and attitudinal aspects, where the behavioral aspect was related with being loyal and continuing to buy a good or service and the attitudinal aspect was related with feeling a sense of belonging or commitment to the good or service [32, 36, 37]. Further, a cognitive approach was also introduced, which referred to the first product or service that comes to the mind of a person while making a purchase [38].

In the studies reviewed for the investigation of the relationships between service quality customer satisfaction and loyalty in retail industry, the researchers reached an agreement that high service quality can ensure high satisfaction, enhance customer retention and patronage, guarantee repurchase, and build loyalty [2, 33, 39-43]. Another point emphasized was that customer satisfaction and loyalty are interrelated since the customers become loyal if they are satisfied, and customer satisfaction creates customer retention and leads to loyalty in the long run $[44,45]$. In apparel retailing, the researchers reached similar conclusions. Focusing on the fashion apparel retailers in their study, Islam et al. revealed that the relation between service quality and both customer satisfaction and loyalty is significant [46]. Investigating customer loyalty in terms of positive word of mouth and repeat purchase intention, Lu and Seock stated that service quality has a great contribution on both customer satisfaction and customer loyalty of the gray customers in apparel department stores [45]. Wong and Sohal confirmed the positive impact of service quality in large chain apparel department stores on the customer loyalty, where it referred to repeat purchase and holding favorable attitude [40]. Dealing with the department stores, Sivadas and Prewitt showed that service quality does not have a direct influence on customer loyalty, but has an impact on customer satisfaction, which contributes toward the likelihood of re-purchasing and recommendation of the department stores [44]. Finally, Chang et al. showed that customer satisfaction is an antecedent for the word of mouth and patronage intention, which can be considered as customer loyalty in active-wear specialty stores [2].

\subsection{Research hypothesis and conceptual framework}

Based on the literature, the proposed hypotheses are stated here and the conceptual framework has been built as seen in Figure 1.

$H 1$ : Service quality performance has a significant effect on customer satisfaction

$\mathrm{H} 2$ : Service quality performance has a significant effect on customer loyalty

H3: Customer satisfaction has a significant effect on customer loyalty

SERVQUAL scale was used in the conceptual framework as the perception-only scale in a hierarchical structure with a second-order construct called service quality. The reason is that the SERVQUAL is a generally accepted and used scale by the academics and it forms the basis of other scales for evaluating service-related attributes.

\section{Research method}

\subsection{Data collection and the questionnaire}

In this study, the service quality was measured by focusing on the perceptions of customers through their experience in the international multi-category sportswear retail chains, such as Intersport, Decathlon, and Sportive in Turkey, and the relationship between service quality, customer satisfaction, and customer loyalty was examined. The data for this study was obtained from a survey established online, which collected the data for a three-week period. The participants were required to answer the questions considering the sportswear retail stores 


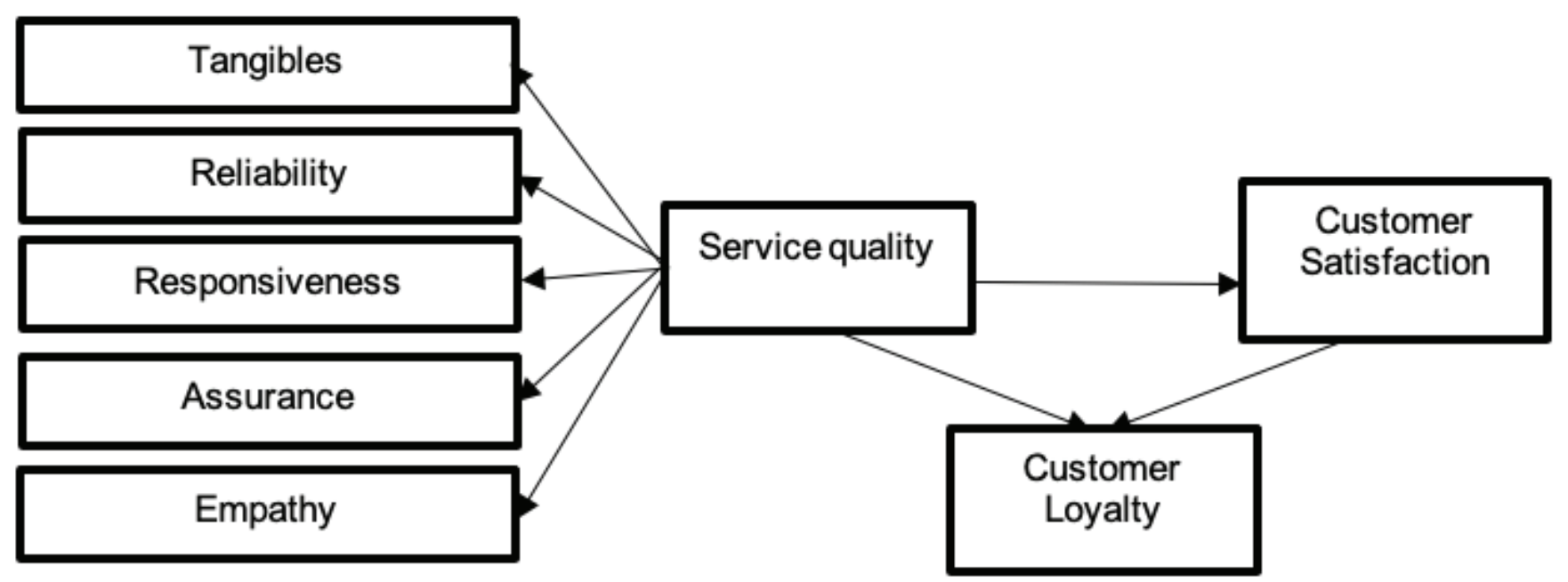

Figure 1. Conceptual framework.

they visited most. The items were established using sevenpoint Likert scale, which ranged from (1) disagree to all to (7) completely agree.

The questionnaire was prepared to contain three parts. The first part included the questions about the demographic properties; the second part included 30 items for measuring service quality, customer satisfaction, and customer loyalty. The part of the questionnaire for measuring service quality was prepared to have 22 items proposed by Parasuraman et al. [21] with the usage of perception only scale. Referring to the customers' fulfillment response to a quality of a service experienced in comparison to other service providers in terms of meeting their expectations, 4 items, which were derived from the previous studies, were asked for measuring the customer satisfaction $[40,47]$. Assessing only the cognitive loyalty aspect, which is the experience-based information about the service, 4 items derived from the previous studies were used to measure the customer loyalty $[40,47]$.

Table 1. The model fit values for the conceptual model.

\subsection{Data analysis}

The evaluation on the data set was statistically made using IBM-SPSS and AMOS 21 (Analysis of moment structure) Program. The normality of the data was examined using the skewness and kurtosis of the data. The multivariate normality was also checked by applying the Mardia's test.

To achieve reliability and validity, the confirmatory factor analysis (CFA) involving two first-order constructs for customer satisfaction and customer loyalty, and one second-order construct for service quality. Some modifications were made on the CFA in checking the factor loadings and modification indices. The model fit was evaluated using the fit indices and comparison of the values of these fit indices with their recommended values is shown in Table 1.

The scale reliability was assessed calculating the Cronbach's alpha (CA). The convergent validity of the conceptual model was tested by considering the average variance extracted (AVE) values and the composite reliability (CR) [49].

\begin{tabular}{|c|c|c|c|}
\hline & $\begin{array}{c}\text { Recommended } \\
\text { values (r.v.) }\end{array}$ & $\begin{array}{c}\text { Model with the } \\
\text { second-order } \\
\text { construct with } \\
\text { five dimensions }\end{array}$ & $\begin{array}{c}\text { Model with the second- } \\
\text { order construct with } \\
\text { three dimensions }\end{array}$ \\
\hline Chi-Square $X^{2}$ & 474.370 & 229.830 \\
\hline Degree of freedom (Df) & & 241 & 111 \\
\hline Chi-Square/degree of freedom (X'/df) & $<3[48]$ & 1.968 & 2.071 \\
\hline Goodness of fit index (GFI) & $>=0.9[49]$ & 0.868 & 0.900 \\
\hline Adjusted goodness of fit index (AGFI) & $>0.8[50]$ & 0.836 & 0.863 \\
\hline Normalized fit index, (NFI) & $>=0.9[49]$ & 0.882 & 0.922 \\
\hline Comparative fit index (CFI) & $>=0.9[49]$ & 0.938 & 0.958 \\
\hline Root mean square residual (RMR) & $<=0.08[49]$ & 0.271 & 0.060 \\
\hline Root mean square of approximation (RMSEA) & $<=0.08[49]$ & 0.062 & 0.065 \\
\hline
\end{tabular}


The proposed hypotheses were tested and the strength of the relationships was calculated using structural equation modeling (SEM). The statistical significance of the hypotheses was evaluated by comparing the actual value of critical ratio in AMOS to the preset critical value, the value of $t$ at the desired two-tailed alpha or $p$-level, and it was taken as $t=1.950$ at $p$-level $=0.050$.

\section{Results}

\subsection{Sample profile}

The data was collected from 251 participants living in Turkey. Among the participants $61.50 \%$ was female and $38.50 \%$ was male. Also, $46.22 \%$ of the participants were aged between "18 and 23 ," which was then followed by $26.29 \%, 18.33 \%$, and $9.16 \%$ corresponding to the participants aged between " 24 and 29 ," "36 and above," and "30 and 35." This is because most of the participants were aged between "18 and $23, " 41.04 \%$ of the participants were still attending undergraduate courses, $37.85 \%$ of the participants were undergraduates, and $8.76 \%$ of the participants were graduates.

\subsection{Results for confirmatory factor analysis}

The normality of the data was checked by using the skewness and kurtosis values and Mardia's test. Since the skewness values were smaller than 3 , and kurtosis values were smaller than 10 , no threat was found to normality [48]. The multivariate kurtosis got the value 186.527 and it was lower than the value 928 calculated according to formula $p(p+2)$, where $p$ is the number of observed variables [51].

CFA accomplishing maximum likelihood estimation procedure was applied. On checking the factor loadings, one item from reliability, one item from responsibility, one item from empathy, two items from satisfaction, and one item from customer loyalty were eliminated from the analysis. Moreover, the modifications were made based on the modification indices of error terms. The model fit values were obtained as stated in Table 1.
The standardized regression weights for the second-order construct service quality was checked and they were found to get values $0.900,0.669,0.637,0.366$, and 0.207 for the firstorder constructs which are reliability, tangibles, assurance, responsiveness, and empathy, respectively, where the relation of the dimension empathy and responsiveness can be expressed to be lower. The two dimensions, which are responsiveness and empathy, having standardized regression weight lower than 0.500 , were discarded to conform to the construct validity test. The model fit values obtained after this modification yielded better fit values are seen in Table 1.

The internal consistency, reliability, and validity of the data were checked by CA, CR, and AVE values. The internal consistency and reliability of the constructs were found satisfactory since CA values were above 0.700 cut off value $(0.848$ for service quality with three dimensions, 0.923 for customer satisfaction, and 0.779 for customer loyalty) as proposed by Nunnally and Bernstein [52]. The CR of all constructs had a value greater than 0.600 ( 0.785 for service quality with three dimensions, 0.928 for customer satisfaction, and 0.781 for customer loyalty) as suggested by Bagozzi and Yi [53]. AVE values, showing the total variance extracted by the latent variables, were found to be higher than 0.500 for all constructs $(0.552$ for service quality with three dimensions, 0.812 for customer satisfaction, and 0.640 for customer loyalty) as recommended by Bagozzi and Yi [53].

\subsection{Results for structural equation modelling}

To determine the validity of the hypotheses statistically, structural equation modeling was applied, and the hypotheses getting $p$ values below 0.050 were stated to be supported. The regression weights and squared multiple correlation values for the dependent constructs was calculated and shown on the arrows and in the boxes, respectively as in Figure 2.

The $R^{2}$ values for the dependent constructs were 0.118 and 0.671 for customer satisfaction and customer loyalty, respectively. Since both $R^{2}$ values are larger than 0.100 , it was appropriate to examine the significance of paths related

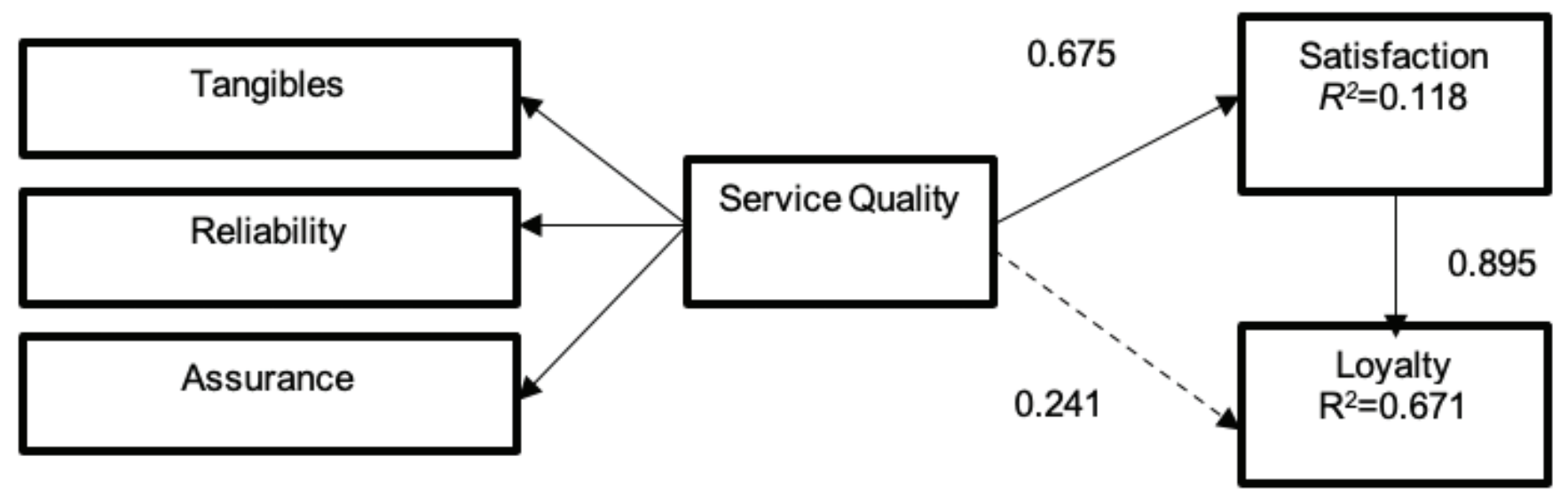

Figure 2. Validated hypotheses for the conceptual model. 
with these constructs. With regard to the hypotheses, the hypotheses $\mathrm{H} 1$ and $\mathrm{H} 3$ were validated for the conceptual model. However, the hypothesis $\mathrm{H} 2$ was rejected as it got a $p$ value $>0.050$. The regression weight indicating the strength of the relationship between service quality and customer satisfaction was determined to be 0.675 . This meant that the service quality had a significant positive impact on the customer satisfaction and if the sportswear retailers increase the quality of the service, this would increase the satisfaction level of the customers. The regression weight representing the relationship between the customer satisfaction and the customer loyalty indicated the value 0.895 . Thus, the satisfaction of the customers was found to exert a high level of influence on the loyalty of the customers, revealing that the satisfied customers are more likely (probable) to be loyal till the end. On the other hand, the quality of the service did not have a direct impact on the customer loyalty, but it seems to have an indirect effect by influencing the satisfaction of the customer.

\section{Discussion}

In this study, service quality in the sportswear retail market was measured and the relationships between the constructs service quality, customer satisfaction, and customer loyalty were investigated. The service quality construct was built as a second-order construct. Nonetheless, some of the dimensions were eliminated after considering the model fit data.

In this regard, the service quality construct had three dimensions, which are tangibles, reliability, and assurance. The empathy- and responsiveness-indicators were discarded because of their lower regression weights. Such findings were observed in previous studies, where some dimensions had weaker relations [54]; alternatively, the empathy was the dimension that behaved differently from the other dimensions of the scale [23, 55]. In fact, service quality could not be built as only one secondorder construct was available in some previous studies $[23,28$, 55]. Specifically, Pantouvakis evaluated the service quality with two second-order constructs, which are physical service quality (including two dimensions, namely tangibles and reliability) and interactive service quality (including three dimensions, namely assurance, empathy, and responsiveness) [28]. Though these three dimensions have an interactive nature, in other studies established in different fields such as transportation and health industry, it was stated that the responsiveness and empathy dimensions contained very similar meanings, considering their interactive capability [56-58]. Thus, despite the findings stating that the dimension empathy and personal relationships have been favored in the studies focused on apparel retailing $[2,41$, 45-46], the discarding of these dimensions can be explained with the fact that these two dimensions could be considered to be differentiated from the service quality delivered by the retail store in participants' point of view, and they could be considered in relation to the personnel working at the sportswear retail store at that time.

Hence, the discarding of empathy and responsiveness can be quite understandable and meaningful, when the findings are reviewed in the perspective of the sportswear product category and sportswear retail market. Since the sportswear products are not assuring the customers that they would make them feel special primarily, the customers do not require special treatment and care, as in the case of the luxury fashion customers [59]. Besides, the sportswear products are usually preferred by the younger generation and their youthfulness is associated with energy and young life styles. The young customers prefer to make their choices by themselves and have higher involvement in product selection [3]. They have the eagerness and ability to search for products and may not hesitate to put extra effort for reaching them [2]. The younger customers might not request empathy from the sales staff in the sportswear retail stores, as in the case of gray customers paying more attention to services such as courteous treatment and assistance from sales staff [45]. On the other hand, the reason why the responsiveness was not found to be an integral part of the service quality might be related with the apparel products in general. This is because most of the apparel customers still do not prefer to return the product, even if they have a problem during use or post purchase [60]. Apprehensiveness in notifying the retail store of defects in the product is usually explicable as a consequence of the relatively lower price levels of the apparel products compared to the type of product categories such as electronics and software [60].

The service quality was associated with the three dimensions (tangibles, reliability, and assurance) loaded under the secondorder service quality construct in the present study. These dimensions can be expressed as the consistency in the physical aspects of the service quality, which can refer to the perceptions about the service quality of the retail store to provide a convenient product mix with expected quality in an accurate setting. Actually, the stores and the physical appearance that characterizes them are already used by brands like Zara even for advertising activities that aim to improve the perceptions of their customers about the product and service quality [61]. Moreover, in a study, where the service quality of Zara was tested, it was found out that the reliability and credibility were the factors that meet the expectations of the customers [39]. Apart from the customers' perception of service quality, tangibles, reliability, and assurance are highly associated with the brand, retailer, or store image. Whereas reliability and assurance are highly associated with the brand-promises and trustworthiness of the brands, the dimension 'tangibles' is also integrated into brand, retailer, or store image by some of the researchers. For instance, Lu and Seock identified the physical aspects and reliability under 'store image' [45]. The association of the tangibles dimension, covering the physical aspects and the dressing of sales staff with the image, is also in accord with the store image theory, and the customers prefer to shop from the brands or stores whose image they like. In fact, in an empirical study established in apparel industry, it was observed that in terms of store choice of bras, the respondents were found to seek congruence between their own profile or image and that of in-store sales staff [62]. Thus, the association of service quality with the dimensions of tangibles, reliability, and assurance can be explained and interpreted in terms of the characteristic of the sportswear products. The sportswear brands and retailers are actually promising the consumers, highly functional, practical, and even innovative products. Therefore, the customers expect 
the sportswear brands and retailers to assure them-in terms of satisfaction of the functional requirements-that they want to trust the brands and the retailers' reliability to keep their promise and finally that they expect to see the sign of this confirmation via tangible properties emphasizing the brand, retailer, or store image.

As stated previously, the service quality construct was found to have a significant influence on the customer satisfaction but not on the customer loyalty in the present study. The significant relationship between service quality and customer satisfaction is compatible with the previous findings, which built service quality constructs with different dimensions in retailing [33, $39,41,45]$ and specifically apparel retailing [18, 44]. However, considering the dimensions of the second-order service quality construct to be tangibles, reliability, and assurance, further similarities can be observed with the literature [39, 41]. Tangibles, referring to the store environment and physical appearance, were confirmed to be one of the most important quality dimensions for the customer satisfaction in apparel retail industry [7]. The other two dimensions, assurance and reliability, might be attached to the trust and security feelings of the customer towards the retailer itself. This is because it is known that a strong reputation and positive predictability could reflect trust on a brand and that they might increase the customer satisfaction [63]. With regard to the relationship between service quality and customer loyalty, the statistical analysis produced insignificant results in the present study. Although the finding was in parallel with the study by Sivadas and Baker-Prewitt, who indicated that service quality had no direct effect on store loyalty [44], this result contradicted the previous studies, which expressed a positive relationship between service quality and the customer loyalty in apparel retailing $[18,40,46]$. This might be attributed to the expression and content of the customer loyalty in question. In the present study, customer loyalty referred to only cognitive loyalty; whereas, Li et al. evaluated loyalty as a long-term commitment with the brand or enterprise and Wong and Sohal identified loyalty as company and employee loyalty, respectively, and finally Islam et al. attached loyalty to revisit-intention and emotional bondage [18, 40, 46]. Moreover, there are many studies in different fields, which found that the customer loyalty is not influenced from the service quality [34, 43, 64].Finally, the analysis of the present study revealed that the customer satisfaction had a significant impact on the customer loyalty, as stated by Islam et al. [46]. Although the number of the studies that have investigated the relationship of service quality with customer satisfaction and loyalty in apparel retailing is very limited, there are many studies in different fields, which found that the customer loyalty is influenced based on the customer satisfaction [34, 43, 64]. All of them pointed out the fact that the service quality did not have a direct influence on the customer loyalty, but that it influences the customer satisfaction, which had a direct influence on the customer loyalty.

\section{Managerial implications}

In the study, the primary dimensions associated with the second-order construct service quality were determined for the sportswear retail market. Although the service quality from the sportswear industry was not found to be directly related with the loyalty, it was found to have a strong impact on the customer satisfaction, which in turn has an impact on customer loyalty. This meant that to increase the customer satisfaction and in turn the customer loyalty, the quality of the service should be improved. These findings emphasized the significance of the service quality. It has been ascertained that the service quality is important for the sales of apparel products as well as the product quality. It might even have a special importance for some of the customers, who seemed to switch from lower tier fashion stores to higher tier fashion stores over time [7]. Therefore, the quality of service given to the sportswear customers should be improved as much as possible.

The dimensions of service quality, which are tangibles, reliability, and assurance, to be associated with the service quality, presents interesting as well as important information about the sportswear products and sportswear market. Reviewing each dimension separately, some specific suggestions can be given to the sportswear retailers. Regarding the dimension tangibles, the retailers can be advised to keep the physical facilities clean, tidy, modern-looking, and attractive in the case that a convenient retail store layout is provided for the customers to find what they need and to move around with ease. Availability of the equipment and visual materials might be provided and attention might be given on the interior de'cor, atmosphere window display, arrangement of merchandise, and even the window display. To provide reliability and assurance, the customer information kiosk or scanners might be placed in the retail stores, where the customer could verify prices and confirm the product information. Besides, reliable information about the products (such as material used, price, or shipping fees) might be displayed on social media platforms such as the internet in general, Facebook, and Instagram in an effort to ensure that customers could have direct online access to the necessary information. The credit and charge account policies (operating hours, payment options, acceptance of major credit cards, availability of store credit card, special discount) might be determined in detail and applied in the same manner in every point of contact with the customers. Moreover, the customers might be given some rights for the product return and they should be kept well informed about these rights. Even a special after-sale service program might be introduced and announced to the customers.

Since all these dimensions are associated with the brand image for the specialty stores and the retailers image for the department stores, it can be advised to the sportswear retailers to arrange the service given in the stores in such a way that it reflects the brand and retail or store image.

Considering that sportswear products present the consumers with fun, joy, enjoyment, activity, and coolness, the following suggestions can be given to the sportswear retailers. Some activities might be arranged within the store allowing the consumers to experience the products in an environment, where the specific product can be tried on the occasion it was designed for. In fact, the young customer, who takes the largest share in the sportswear retail market, expects to have access 
to that kind of activities due to the increasing importance of experiential marketing in the present-age marketing scenario. Experiential marketing helps to make the consumers motivated, since they expect the purchase experience to possess hedonic qualities such as excitement, entertainment, escapism, fantasy, and fun [16]. Further, the services in the retail stores became the basic tool with which to enhance the customers' shopping experience [41].

Apart from presenting joy and fun, the sportswear retailers might present differentiated services according to their image in relation to their point of differentiation. The sportswear retailers differentiating themselves via innovation might organize the innovative services. For instance, the sportswear retailers might give the information of the product presented in the stores using augmented reality tools. This type of informationsharing emphasizes the perception of the consumer about innovativeness on one hand; it decreases the need for the sales staff, enhances the accuracy of the information shared, and assures the consumers about their image on the other hand. Moreover, the customers might enjoy participating in that kind of activity and having that kind of experience. The sportswear brands putting more emphasis on fashion and trends might bring some specific features of tangibles to the forefront. For instance, the fashion shows might be broadcasted on the LED screens. Since the dimension 'tangibles' includes also the dressing of the sales staff [2], the sales staff might wear the products of the retails-thereby reflecting brand identity-while they are working.

Although the empathy and responsiveness dimensions were eliminated from the analysis, they should be completely overlooked actually. Since the dimension empathy was not associated with the service quality, but rather the dimension assurance was found to be associated with the service quality, it might be advised to the sportswear retailers that they ought to train the sales staff about the products. In this respect, personal empowerment programs might be given in relation to the necessary product knowledge and the store personnel/ staff might continuously be informed about the differentiating properties of the new products. In fact, the expectation of the sportswear customers is for the educated sales staff to assist them when they have questions or need product advice, and this was underlined in a previous study [2]. Further, the sales staff might be educated and given expertise about transactions, prices, and inventories. The customers should be assured that they will be given attention when they want to return or exchange the product or when they have some complaints about either the product or the service. Similarly, although responsiveness, which is the dimension of the service quality associated with the returns, was discarded and not analyzed in detail in the study, it should not be ignored completely since there is a danger for the unsatisfied customer to switch the other brands. On the other hand, with regard to interpersonal communication, the store personnel should be warned about the fine line between being helpful and being pesky [60].

\section{Conclusion}

This study validated the model built to measure the service quality in the sportswear retail market, and to find the relationship between service quality, customer satisfaction, and customer loyalty. In the model, the service quality derived from the SERVQUAL scale with three dimensions, which are tangibles, reliability, and assurance, had a direct effect on customer satisfaction and this in turn was able to exert an influence on customer loyalty. Considering the model fit data using three dimensions of the SERVQUAL scale, it can be stated that the service quality can be established as a secondorder construct.

The major implication of this study is regarding the determination of the features to emphasize to increase the satisfaction of the customer, which will provide loyalty in return. It was put forward that this specific product category requires a special type of service. Some managerial implications were given focusing on the sportswear products and sportswear retail marketing activities.

The researchers living in different parts of the world can implement the model on different populations to make comparisons in terms of customer behaviors in sportswear retail stores. Moreover, considering the findings of this study, which hypothesized that the service quality was not influential on loyalty directly, other aspects of the customer loyalty or the sportswear-product-related features can be suggested for integration into the model as a future work. The characteristics of sportswear products such as brand, functionality, and aesthetics can also be analyzed to observe the influence of both product and service characteristics on customer satisfaction and loyalty. Moreover, the mediating role of customer satisfaction in that relationship can be analyzed in future studies.

\section{References}

[1] Sportswear Industry: Global Market to Reach US\$ 108.7 Bn by the End of 2025, www.globenewswire.com, accessed January 2020.

[2] Chang, H. J., Cho, H. J., Turner, T., Gupta, M., Watchravesringkan, K. (2015). Effects of store attributes on retail patronage behaviors: Evidence from activewear specialty stores. Journal of Fashion Marketing and Management, 19(2), 136-153.

[3] Ko, E., Taylor, C. R., Sung, H., Lee, J., Wagner, U., et al. (2012). Global marketing segmentation usefulness in the sportswear industry. Journal of Business Research, 65(11), 1565-1575.

[4] Team, O. M. I. G. Sportswear.

[5] Levitt, T. (1980). Marketing success through differentiation - of anything. Harvard Business Review, 58(1), 83-91.

[6] Loomba, A. P. (1996). Linkages between product distribution and service support functions. International Journal of Physical Distribution \& Logistics Management, 26(4), 4-22. 
[7] Leung, C. S., To, C. K. (2001). Measuring perceived service quality of fashion stores: A test-retest reliability investigation. Journal of Fashion Marketing and Management: An International Journal, 5(4), 324-329.

[8] Jamal, A., Naser, K. (2002). Customer satisfaction and retail banking: An assessment of some of the key antecedents of customer satisfaction in retail banking. International Journal of Bank Marketing, 20(4), 146-160.

[9] Mosahab, R. (2010). Service quality, customer satisfaction and loyalty: A test of mediation. International Business Research, 3(4), 72-80.

[10] Baker, D. A., Crompton, J. L. (2000). Quality, satisfaction and behavioral intentions. Annals of Tourism Research, 27(3), 785-804.

[11] Gremler, D. D., Brown, S. W. (1996). Service loyalty: Its nature, importance, and implications. Advancing Service Quality: A Global Perspective, 5, 171-181.

[12] Arslan, M., Zaman, R. (2015). Impact of brand image and service quality on consumer purchase intentions. A Study of Retail Stores in Pakistan. Research on Humanities and Social Sciences, 4(22), 98-105.

[13] Mehta, S. C., Lalwani, A. K., Han, S. L. (2000). Service quality in retailing: Relative efficiency of alternative measurement scales for different product-service environments. International Journal of Retail \& Distribution Management, 28(2), 62-72.

[14] To, W. M., Tam, J. F., Cheung, M. F. (2013). Explore how Chinese consumers evaluate retail service quality and satisfaction. Service Business, 7(1), 121-142.

[15] Siu, N. Y., Tak-Hing Cheung, J. (2001). A measure of retail service quality. Marketing Intelligence \& Planning, 19(2), 88-96.

[16] Carpenter, J. M., Fairhurst, A. (2005). Consumer shopping value, satisfaction, and loyalty for retail apparel brands. Journal of Fashion Marketing and Management: An International Journal, 9(3), 256-269.

[17] Chi, T., Kilduff, P. P. (2011). Understanding consumer perceived value of casual sportswear: An empirical study. Journal of Retailing and Consumer Services, 18(5), 422429.

[18] Li, M., Liu, Y., Zhang, W. (2008). Model and empirical study on service quality affecting customer loyalty of sportswear brands. WICOM'08,(Dalian, China, 12-17 Oct 2008),1-4.

[19] Grönroos, C. (1982). Strategic management and marketing in the service. Swedish School of Economics and Business Administration (Helsinfors).

[20] Lehtinen, U., Lehtinen, J. R. (1991). Two approaches to service quality dimensions. Service Industries Journal, 11(3), 287-303.

[21] Parasuraman, A., Zeithami, V. A., Berry, L. (1988). SERVQUAL: A multiple-item scale for measuring customer perceptions of service care. Journal of Retailing, 64(1), 1240.

[22] Finn, D.W., Lamb, C.W. (1991). An evaluation of the SERVQUAL scales in a retailing setting. Advances in Customer Research, 18, 483-490.

[23] Gefen, D. (2002). Customer loyalty in e-commerce. Journal of the Association for Information Systems, 3(1), 27-71.

[24] Hartline, M. D., Ferrell, O. C. (1996). The management of customer-contact service employees: An empirical investigation. Journal of Marketing, 60(4), 52-70.
[25] Cronin Jr., J. J., Taylor, S. A. (1992). Measuring service quality: $A$ reexamination and extension. Journal of Marketing, 56(3), 55-68.

[26] Dabholkar, P. A., Thorpe, D. I., Rentz, J. O. (1996). A measure of service quality for retail stores: Scale development and validation. Journal of the Academy of Marketing Science, 24(1), 3-16.

[27] Kang, G. D. (2006). The hierarchical structure of service quality: Integration of technical and functional quality. Managing Service Quality: An International Journal, 16(1), 37-50.

[28] Pantouvakis, A. (2010). The relative importance of service feature in explaining customer satisfaction: A comparison of measurement models. Managing Service Quality: An International Journal, 20(4), 366-387.

[29] Untachai, S. (2013). Modeling service quality in hospital as a second order factor, Thailand. Procedia-Social and Behavioral Sciences, 88, 118-133.

[30] Jen, W., Tu, R., Lu, T. (2011). Managing passenger behavioral intention: An integrated framework for service quality, satisfaction, perceived value, and switching barriers. Transportation, 38(2), 321-342.

[31] Kim, E. Y., Jackson, V. P. (2009). The effect of E-SERVQUAL on e-loyalty for apparel online shopping. Journal of Global Academy of Marketing, 19(4), 57-65.

[32] Thomas, S. (2013). Linking customer loyalty to customer satisfaction and store image: A structural model for retail stores. Decision, 40(1-2), 15-25.

[33] Naik, C. K., Gantasala, S. B., Prabhakar, G. V. (2010). Service quality (SERVQUAL) and its effect on customer satisfaction in retailing. European Journal of Social Sciences, 16(2), 231-243.

[34] Alnaser, F., Ghani, M., Rahi, S. (2017). The impact of SERVQUAL model and subjective norms on customer's satisfaction and customer loyalty in Islamic Banks: $A$ Cultural Context. International Journal of Economics \& Management Sciences, 6(5), 455.

[35] Sum, C. Y., Hui, C. L. (2009). Salespersons' service quality and customer loyalty in fashion chain stores: A study in Hong Kong retail stores. Journal of Fashion Marketing and Management: An International Journal, 13(1), 98-108.

[36] Clottey, T. A., Collier, D. A., Stodnick, M. (2008). Drivers of customer loyalty in a retail store environment. Journal of Service Science (JSS), 1(1), 35-48.

[37] Biscaia, A. R., Rosa, M. J., e Sa, P. M., Sarrico, C. S. (2017). Assessing customer satisfaction and loyalty in the retail sector. International Journal of Quality \& Reliability Management, 34(9), 1508-1529.

[38] Caruana, A. (2002). Service loyalty: The effects of service quality and the mediating role of customer satisfaction. European Journal of Marketing, 36(7/8), 811-828.

[39] Chan, T. J., Goh, M. L. (2019). Determinants of service quality and customer satisfaction of Retail Clothing Company. Journal of Business and Social Review in Emerging Economies, 5(2), 295-304.

[40] Wong, A., Sohal, A. (2003). Service quality and customer loyalty perspectives on two levels of retail relationships. Journal of Services Marketing, 17(5), 495-513.

[41] Bhaskar, N. U., Shekhar, B. R. (2011). Impact of service quality on apparel retail customer satisfaction-a study of select metropolitan city Hyderabad. Journal of Management Research, 3(2), 1-13. 
[42] Sivapalan, A., Jebarajakirthy, C. (2017). An application of retailing service quality practices influencing customer loyalty toward retailers. Marketing Intelligence \& Planning, 35(7), 842-857.

[43] Cristobal, E., Flavian, C., Guinaliu, M. (2007). Perceived e-service quality (PeSQ) measurement validation and effects on customer satisfaction and web site loyalty. Managing Service Quality: An International Journal, 17(3), 317-340.

[44] Sivadas, E., Baker-Prewitt, J. L. (2000). An examination of the relationship between service quality, customer satisfaction, and store loyalty. International Journal of Retail \& Distribution Management, 28(2), 73-82.

[45] Lu, Y., Seock, Y. K. (2008). The influence of grey consumers' service quality perception on satisfaction and store loyalty behavior. International Journal of Retail \& Distribution Management, 36(11), 901-918.

[46] Islam, M. A., Khadem, M., Sayem, A. (2012). Service quality, customer satisfaction and customer loyalty analysis in Bangladesh apparel fashion retail: An empirical study. International Journal of Fashion Design, Technology and Education, 5(3), 213-224.

[47] Setó-Pamies, D. (2012). Customer loyalty to service providers: Examining the role of service quality, customer satisfaction and trust. Total Quality Management \& Business Excellence, 23(11-12), 1257-1271.

[48] Kline, R. B. (2015). Principles and practice of structural equation modeling. New York: Guilford publications.

[49] Hair, J.F. (2006). Multivariate data analysis (6th ed.). New Jersey: Englewood Cliffs, Prentice Hill. 50. Chau, P. Y. (1996). An empirical assessment of a modified technology acceptance model. Journal of Management Information Systems, 13(2), 185-204.

[50] Raykov, T., Marcoulides, G. A. (2012). An introduction to applied multivariate analysis. New York: Routledge Taylor and DFrancis Group. 52. Nunnally, J.C., Bernstein, I.H. (1994). Psychometric theory (3rd ed.), New York: McGrawHill.

[51] Bagozzi, R. P., Yi, Y. (1988). On the evaluation of structural equation models. Journal of the Academy of Marketing Science, 16(1), 74-94.
[52] Zhou, T., Zhang, S., Ji, B. (2010). Exploring the effect of online banking service quality on users' continuance usage. In 2010 2nd International Conference on E-business and Information System Security (pp. 1-4). IEEE.

[53] Sánchez-Hernández, R. M., Martinez-Tur, V., Peiró, J. M., Ramos, J. (2009). Testing a hierarchical and integrated model of quality in the service sector: Functional, relational, and tangible dimensions. Total Quality Management, 20(11), 1173-1188.

[54] An, M., Noh, Y. (2009). Airline customer satisfaction and loyalty: Impact of in-flight service quality. Service Business, 3(3), 293-307.

[55] Zhou, L. (2004). A dimension-specific analysis of performance-only measurement of service quality and satisfaction in China's retail banking. Journal of Services Marketing, 18(7), 534-546.

[56] Dewi, F. D., Sudjana, G., Oesman, Y. M. (2011). Patient satisfaction analysis on service quality of dental health care based on empathy and responsiveness. Dental Research Journal, 8(4), 172-177.

[57] McKechnie, S., Valdez, A. R. (2017). Understanding luxury experiences within the lifeworlds of millennials. In: Marketing at the Confluence between Entertainment and Analytics. Cham: Springer. pp. 1099-1104.

[58] Leen, J. Y., Ramayah, T. (2011). Validation of the RSQS in apparel specialty stores. Measuring Business Excellence, 15(3), 16-18.

[59] Mataraarachchi, R. (2015). Enabling the transition from product provider to service provider an empirical investigation in the apparel industry (Doctoral dissertation).

[60] Michon, R., Yu, H., Smith, D., Chebat, J. C. (2008). The influence of mall environment on female fashion shoppers' value and behaviour. Journal of Fashion Marketing and Management: An International Journal, 12(4), 1361-2026.

[61] Jones, C., Kim, S. (2010). Influences of retail brand trust, off-line patronage, clothing involvement and website quality on online apparel shopping intention. International Journal of Customer Studies, 34(6), 627-637.

[62] Chang, H. H., Wang, H. W. (2007). The relationships among e-service quality, value, satisfaction and loyalty in online shopping. In Borghini, S. et al. (Ed.).E - European Advances in Consumer Research. Duluth, MN: Association for Consumer Research. 